\title{
Description of the Neochoerus specimens from the late Pleistocene (Rancholabrean) of Chiapas, and comments on the taxonomic identity of the fossil capybaras from other Mexican localities
}

\section{Descripción de especimenes de Neochoerus del Pleistoceno (Rancholabreano) tardío de Chiapas, y comentarios sobre la taxonomía de los capibaras fósiles de otras localidades mexicanas}

Gerardo Carbot-Chanona ${ }^{1, *}$,Joaquín Eng-Ponce², Luis Enrique Gómez-Pérez

${ }^{1}$ Museo de Paleontología "Eliseo Palacios Aguilera", Dirección de Paleontología, Secretaría de Medio Ambiente e Historia Natural. Calzada de Los Hombres Ilustres s/n, 29000, Tuxtla Gutiérrez, Chiapas, Mexico.

${ }^{2}$ Laboratorio de Paleontología, Facultad de Biología, Universidad Michoacana de San Nicolás de Hidalgo. Av. Francisco J. Múgica s/n, Ciudad Universitaria, 58030, Morelia, Michoacán, Mexico.

* Corresponding author: (Carbot-Chanona) gfcarbot@gmail.com

\section{ABSTRACT}

The capybara Neochoerus aesopi is an extinct giant rodent that inhabited North, Central, and South America during the Rancholabrean/Lujanian (late Pleistocene). In Mexico, only $\mathcal{N}$. aesopi has been reported from Tlapacoya, Mexico State; Chapala lake, Jalisco; and La Cinta-Portalitos, on the border of Michoacán and Guanajuato. Here, we describe $\mathcal{N}$. aesopi remains from the late Pleistocene at Los Mangos locality, Villaflores municipality, Chiapas, Mexico. In addition, the capybara material from Jalisco and Puebla, referred as Hydrochoerus sp. and Neochoerus sp., respectively, is reexamined. The mandibular and dental morphological characteristics and measurements of the specimens examined from Jalisco and Puebla allow this material to be referred as $\mathcal{N}$. aesopi. The definitive identification of this species broadens its spacial range in North America.

Keywords: Capybara, Neochoerus, Hydrochoerus, taxonomy, Pleistocene, Mexico.

\section{RESUMEN}

El capibara Neochoerus aesopi es un roedor gigante extinto que habitó Norte, Centro y Sudamérica durante el Rancholabreano/ Lujaniano (Pleistoceno tardío). En México, sólo N.․ aesopi ha sido reportado para Tlapacoya, Estado de México; el lago de Chapala, Falisco y La Cinta-Portalitos, en los límites de Michoacán-Guanajuato. Aqui describimos los restos de $\underline{\mathcal{N}}$. aesopi encontrados en los sedimentos del Pleistoceno tardío que afloran en la localidad Los Mangos, en el Municipio de Villaflores, Chiapas, México. También, reexaminamos el material de capibaras de Falisco y Puebla (referido como Hydrochoerus sp. $y$ Neochoerus sp., respectivamente). Las características morfológicas mandibulares $y$ dentales, así como las medidas de los especimenes examinados de Falisco y Puebla permiten referirlos también como $\underline{\mathcal{N}}$ a aesopi. La identificación definitiva de esta especie amplía su rango geográfico en América del Norte.

Palabras clave: Capibara, Neochoerus, Hydrochoerus, taxonomía, Pleistoceno, México. 


\section{Introduction}

The capybaras (Rodentia: Caviidae: Hydrochoerinae) are large rodents that lived in North and South America from the Miocene to the recent. Only two genera are known from the late Pleistocene, Hydrochoerus and Neochoerus (Kurtén and Anderson, 1980). Hydrochoerus is represented by two living species: $H$. hydrochaeris and $H$. isthmius. Today, Hydrochoerus hydrochaeris inhabits Venezuela, Brazil, Paraguay, Uruguay, and eastern Colombia. It also inhabits the Amazon basin of Ecuador, Peru, and Bolivia, as well as northeastern to southern Argentina (Mones and Ojasti, 1986). The species has a late Pleistocene fossil record from Curaçao, Uruguay, Brazil, and Argentina (Mones, 1991; Kerber and Ribeiro, 2011) and Hydrochoerus isthmius inhabits Panama, western Colombia, and western Venezuela (Woods and Kilpatrick, 2005) and does not have a fossil record. Only two species of Hydrochoerus are represented in the fossil record: $H$. ballesterensis from late Pliocene to early Pleistocene of the Villa Ballester, Argentina (Mones, 1991), and H. gaylordi from late Pliocene to early Pleistocene of Grenadines Bank, island of Grenada, Lesser Antilles island-arc (MacPhee et al., 2000).

Neochoerus is an extinct genus closely related to Hydrochoerus (Vucetich et al., 2014), with a fossil record throughout the late Pliocene to the late Pleistocene of North and South America (Mones, 1991). Neochoerus was erected by Hay (1926) for the species Hydrochoerus pinckneyi, which he described based on a single M3 (third upper molar) from the Pleistocene of South Carolina (Hay, 1923).

Currently, six species are recognized: (i) $\mathrm{Neo}^{-}$ choerus occidentalis from Blancan-Irvingtonian (late Pliocene-early Pleistocene) of Sonora and Jalisco (Carranza-Castañeda, 2016); (ii) $\mathcal{N}$. cordobai from Blancan III (early Pliocene) of Guanajuato (Carranza-Castañeda, 2016), referred as Phugatherium dichroplax by Vucetich et al. (2015); (iii) $\mathcal{N}$. tarijensis from Ensenadian (middle Pleistocene) of Tarija,
Bolivia; (iv) $\mathcal{N}$. fontanai from late Pliocene to early Pleistocene of Villa Ballester, Buenos Aires, Argentina (although Mones [1991] considered it a nomen dubium); (v) $\mathcal{N}$. sulcidens from the Lujanian (late Pleistocene) of Brazil and Uruguay; and (vi) $\mathcal{N}$. aesopi from the Rancholabrean/Lujanian (late Pleistocene) of North, Central, and South America (Mones, 1991; Lucas et al., 2008). Occasionally, $\mathcal{N}$. pinckneyi from South Carolina, USA (Hay, 1923, 1926) has been considered valid by some authors (e.g, Álvarez, 1969; Kurtén and Anderson, 1980; Rufolo, 1998; Carranza-Castañeda, 2016), but it was considered a synonymy of $\mathcal{N}$. aesopi by Mones (1991), because both taxa came from the same locality.

The only North American Rancholabrean species, $\mathcal{N}$. aesopi, has been described in Mexico from Tlapacoya, Mexico State (referred to as $\mathcal{N}$. pinckneyi; Álvarez, 1969); La Cinta-Portalitos locality, on the border of Michoacán and Guanajuato; and Chapala lake, Jalisco (Lucas, 2008; Eng-Ponce, 2018). Other records of the genus include $\mathcal{N}$. cordobai from the Blancan to Irvingtonian of Guanajuato (Carranza-Castañeda and Miller, 1988), and $\mathcal{N}$. occidentalis from Irvingtonian of Jalisco and Sonora (Carranza-Castañeda et al., 1981; Shaw, 1981; Shaw and McDonald, 1987; Carranza-Castañeda, 2016). In addition, specimens referred to Hydrochoerus from the late Pleistocene of Media Luna lagoon, San Luis Potosí; Térapa, Sonora; Chapala lake, Jalisco; and Valsequillo, Puebla (Hernández-Junquera, 1977; Pichardo, 1997; Mead et al., 2006; Carranza-Castañeda, 2016), and indeterminate hydrochoerids from Los Tanques, Zacatecas (Lozano-Ramos et al., 2006) have been reported. The fossil record of capybaras in Mexico is poorly known. Therefore, the aim of this work is to formally describe the capybaras specimens recovered from Chiapas state, adding the first locality with these rodents in south-southeastern Mexico. We also comment on the taxonomic identity of the late Pleistocene capybara specimens from other localities in Mexico. 

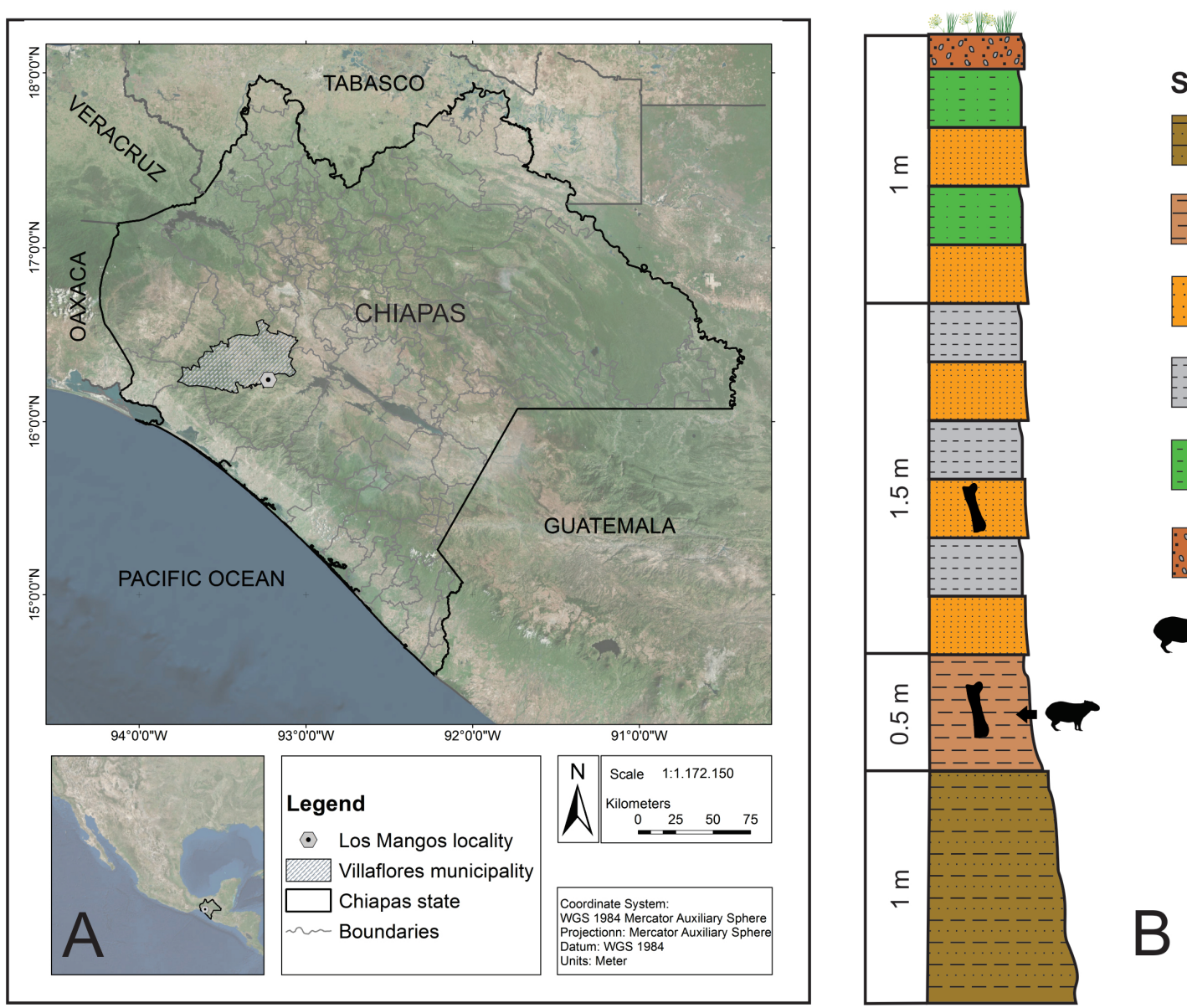

Figure 1 Location (A), and stratigraphic section (B) of the Los Mangos, Villaflores, Chiapas, Mexico.

\section{Study area}

The material described in this work was collected from the Los Mangos locality, near downtown Villaflores, at $16^{\circ} 14^{\prime} 25^{\prime \prime} \mathrm{N}$ and $93^{\circ} 13^{\prime} 28^{\prime \prime} \mathrm{W}$ (Figure 1A). A sequence of $4 \mathrm{~m}$ thick lacustrine sediments crops out there (Figure 1B). The base of the section is composed of $1 \mathrm{~m}$ of coarse to fine sand with granular gravel. Over the base section, there is a $0.50 \mathrm{~m}$ layer of light brown silty clay where $\mathrm{NeO}^{-}$ choerus aesopi material reported here was collected, in association with Glyptotherium floridanum, Odocoileus virginianus, Equus mexicanus, E. conversidens, and Bison sp. remains (Gómez-Pérez and Carbot-Chanona, 2012; Carbot-Chanona and Gómez-Pérez, 2014). Stratigraphically above this bed is a 1.50 $\mathrm{m}$ layer composed of alternating beds of brown silt and reddish-brown fine sand. In this section, $G$. floridanum remains have been collected. The next layer is composed of sandy silt and fine sand, 1 $m$ thick. The upper part of the sequence consists of soil with organic matter. The presence of Bison sp. is indicative of the Rancholabrean NALMA (North American Land Mammal Ages biochronology, late Pleistocene) for the bearing deposits (Bell et al., 2004).

\section{Materials and methods}

\subsection{ANALYZED MATERIAL}

Specimens used in this study include: IHNFG4865, a fragment of maxilla with complete right M3; IHNFG-4866, an almost complete lower jaw, with left and right $\mathrm{p} 4-\mathrm{m} 3$ tooth rows and both 

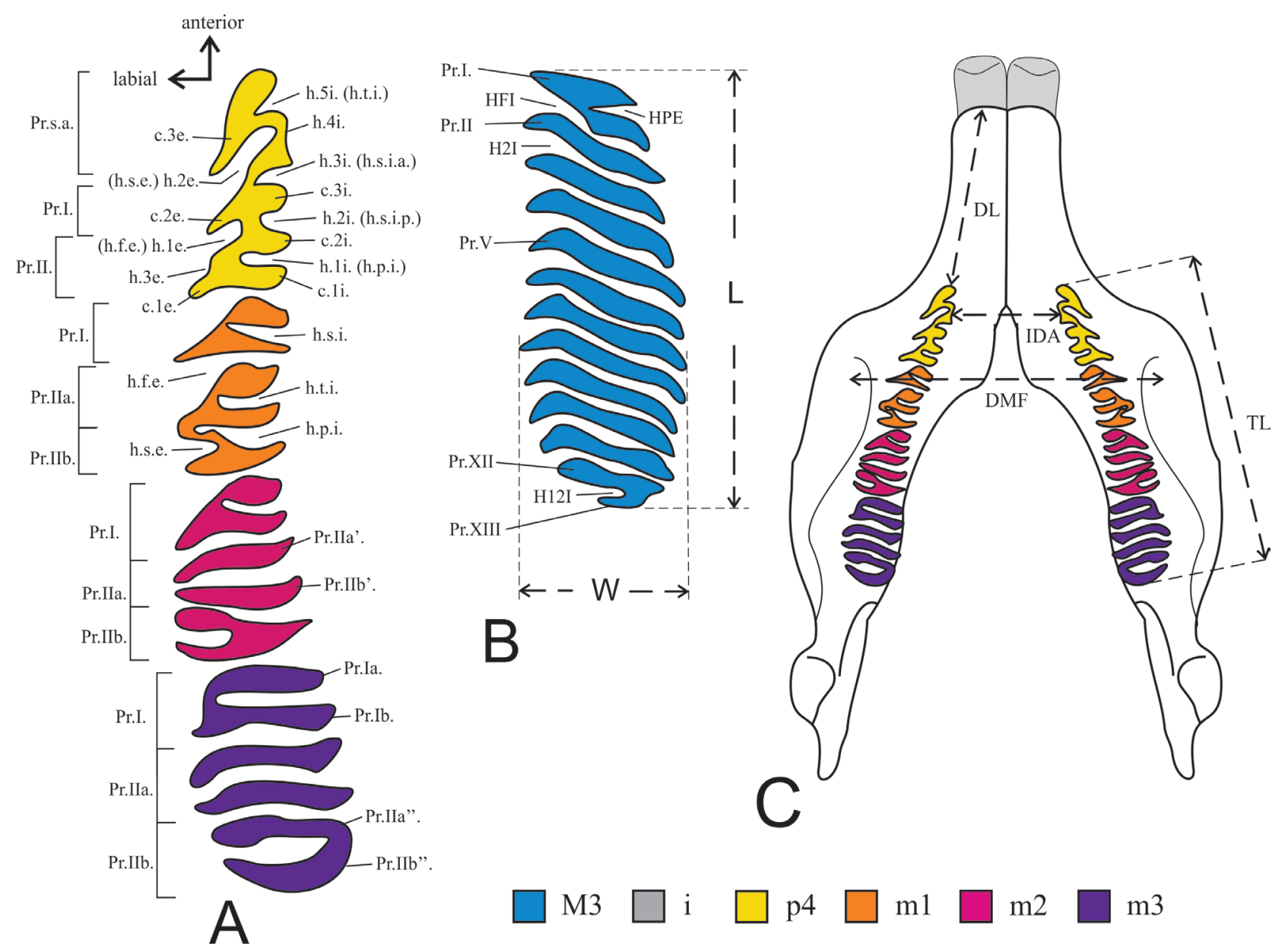

Figure 2 Nomenclature of the lower (A) and upper teeth (B), modified from Mones (1991), and some mandible measurements (C) taken from Carranza-Castañeda (2016). Dental abbreviations: i, lower incisor; p4, fourth lower premolar; $\mathrm{m} 1$, first lower molar; $\mathrm{m} 2$, second lower molar, m3: third lower molar; M3, third upper molar; h.1-5i., first-fifth internal fissure; h.1-3e., first-third external fissure; c.1-3e., first-third external column; c.1-3i., fist-third internal column; h.s.e., secondary external fissure; h.f.e., fundamental external fissure; h.t.i., tertiary internal fissure; h.s.i., secondary internal fissure; h.s.i.a., anterior secondary internal fissure; h.s.i.p., principal secondary internal fissure; h.p.i., primary internal fissure; HFI, fundamental internal fissure; H2-12I, second-twelveth internal fissure; HPE, principal external fissure; Pr.I, first prism; Pr.II, second prism; Pr.V, fifth prism; Pr.XII, twelfth prism; Pr.XIII, thirteenth prism; Pr.s.a., secondary anterior prism of p4; Pr.la-Pr.la', anterior plate of first prism; Pr.lb-Pr.lb', posterior plate of first prism; Pr.lla-Pr.Ila', anterior plate of second prism; Pr.llb-Pr.Ilb', posterior plate of second prism. Measurements abbreviation: L, length; W, width; DL, diastema length; TL, toothrow length; IDA, internal distance between the alveoli of p4; DMF, distance of the masseteric fossa through the Pr.I of the $\mathrm{m} 1$.

incisives preserved; IHNFG-4873, left hemi-mandible with an incisive, p4 and m1; IHNFG-5760, occipital part of the skull; and IHNFG-5761, a pelvic girdle. Specimens were recovered using the traditional vertebrate paleontology methods, and cleaned with needles, airscribe, and soft bristle brushes to remove sediment. The broken parts were joined with commercial glue insoluble to water, and the fissures were filled with epoxy clay. Specimens are housed at Paleontological
Collection of the Paleontological Museum "Eliseo Palacios Aguilera", Secretaría de Medio Ambiente e Historia Natural, Chiapas, Mexico.

\subsection{NOMENGLATURE}

We use the nomenclature for upper and lower dentition of capybaras (Figure 2) proposed by Mones (1975a, 1991), adapted and used by other authors (e.g. Kerber and Ribeiro, 2011; Vucetich 
et al., 2015; Carranza-Castañeda, 2016). Upper and lower dentition are identified by uppercase and lowercase letters, respectively (e.g., M1, m1). For the cranial, mandibular and postcranial elements the nomenclature was based on König and Liebich (2007), Bode et al. (2013) and Brombini et al. (2018). In the text, we employ the name $\mathcal{N}_{e 0^{-}}$ choerus cordobai because it is the first name used in the original description (see Carranza-Castañeda and Miller, 1988). Carranza-Castañeda (2016) used the name $\mathcal{N}$. cordobae and did not explain the reason for the change of the taxonomic name, and there is no previous work where modifications in the nomenclature are discussed.

\subsection{MEASUREMENTS AND PHOTOGRAPHS}

The measurements were obtained with a digital caliper with $0.01 \mathrm{~mm}$ accuracy following Mones (1991) and Carranza-Castañeda (2016), as shown in Figure 2. The measurements of Neochoerus pinckneyi, $\mathcal{N}$. aesopi (mean), $\mathcal{N}$. sulcidens (mean), $\mathcal{N}$. tarijensis (mean), $\mathcal{N}$. cordobai, $\mathcal{N}$. occidentalis, and Hydrochoerus hydrochaeris used for comparison were obtained from the literature (Carranza-Castañeda and Miller, 1988; Mones, 1991; Sanders, 2002; Kerber and Ribeiro, 2011; Carranza-Castañeda, 2016). The measurements of $\mathcal{N}$. occidentalis from Sonora were obtained from the figures presented in Carranza-Castañeda (2016) using ImageJ software (Rasband, 2012). The comparative bivariate plots were elaborated in JMP version 8 (SAS, 2008), using the measurements of Appendix 1 and 2 (Supplementary Material).

The photographs were taken with a digital camera Canon XS, using a lightbox and indirect lighting. Later, the images were processed in Adobe Illustrator to erase the background. The final figures were made in CorelDraw X8.

\subsection{INSTITUTIONAL ABBREVIATIONS}

AMNH, American Museum of Natural History, Ney York, USA; AWC, Arizona Western College, Arizona, USA; IHNFG, Instituto de Historia
Natural, Fósil Geográfico, Chiapas, Mexico (historically is the acronym for the Paleontological Collection of the Secretaría de Medio Ambiente e Historia Natural, Chiapas, Mexico); INAH, Instituto Nacional de Antropología e Historia, Ciudad de Mexico, Mexico; MCN-D, Museu de Ciências da Pontifícia Universidade Católica do Rio Grande do Sul, Uruguaiana, Brazil; MCN-PV, Coleção de Paleovertebrados do Museu de Ciências da Pontifícia Universidade Católica do Rio Grande do Sul, Uruguaiana, Brazil; MCPU, Museu de Ciências da Pontifícia Universidade Católica do Rio Grande do Sul, Uruguaiana, Brazil; MCPU-PV, Coleção de Paleovertebrados do Museu de Ciências da Pontifícia Universidade Católica do Rio Grande do Sul, Uruguaiana, Brazil; MCPU-M, Coleção de Mastozoologia do Museu de Ciências da Pontifícia Universidade Católica do Rio Grande do Sul, Uruguaiana, Brazil; MLP, Museo de La Plata, La Plata, Argentina; MPGJ, Museo de Paleontología Geociencias, Querétaro, Mexico; TMM, Jackson School of Geosciences, Vertebrate Paleontology Laboratory, The University of Texas at Austin, Texas, USA.

\section{Results}

\subsection{SYSTEMATIC PALEONTOLOGY}

Class MAMMALIA Linnaeus, 1758

Orden RODENTIA Bowdich, 1821

Infraorder Hystricognathi Tullberg, 1899

Family Caviidae Fischer, 1817 sensu Waterhouse, 1839

Subfamily Hydrochoerinae (Gray, 1825) Gill, 1872

Genus Neochoerus Hay, 1926

Neochoerus aesopi (Leidy, 1853)

Holotype. Fragment of the incisive (position indeterminate), described as Oromys aesopi, collected by Prof. Holmes on the Ashley River, Charleston, South Carolina, USA (Leidy, 1853). Housed at the AMNH under the catalog number FM 485. 


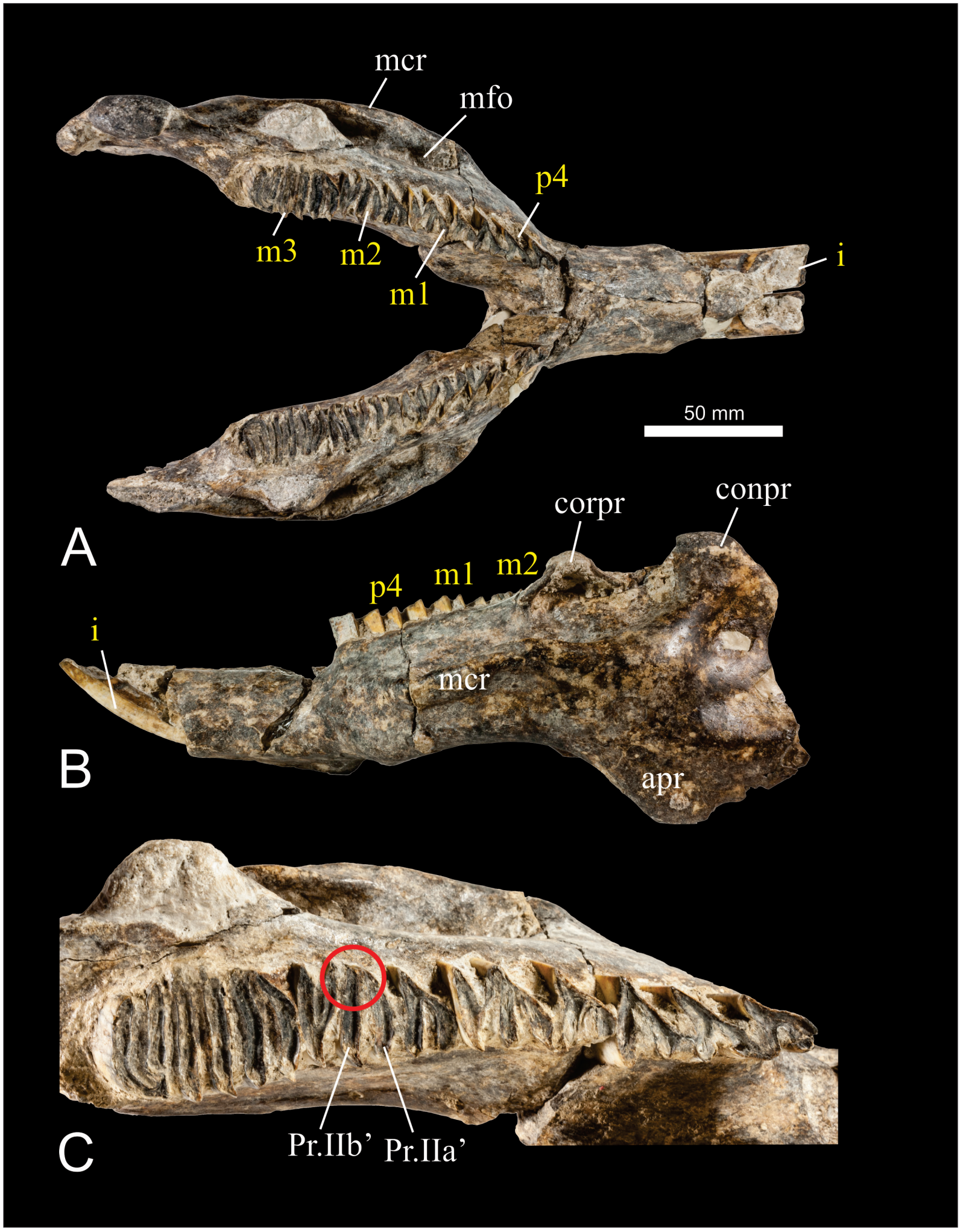

Figure 3 IHNFG-4866, nearly complete mandible from Los Mangos locality, Villaflores, Chiapas, in occlusal (A) and left lateral (B) view. Detail of the left toothrow in occlusal view (C); the red circle indicates the unusual union between the Pr.Ila' and Pr.Ilb'. Abbreviations: apr, angular process; conpr, condylar process; corpr, coronoid process; mcr, masseteric crest; mfo, masseteric fossa. Dental abbreviations as in Figure 2. 
Synonymy. Oromys aesopi (Leidy, 1853); Hydrochoerus aesopi (Leidy, 1856); Hydrochoerus magnus (Gervais and Ameghino, 1880); Hydrochoerus robustus (Leidy, 1887); Hydrochoerus holmesi (Simpson, 1928); Neochoerus magnus (Kraglievich, 1930); Neochoerus robustus (Kraglievich, 1930); Prohydrochoerus sirasakae (Spillmann, 1941); Protohydrochoerus schirasakae [sic] (Spillmann, 1948); Neochoerus (Neochoerus) sirasakae (Hoffstteter, 1952); Neochoerus sirasakae (Mones, 1975b); Neochoerus pinckneyi (Mones, 1991).

\subsection{DESGRIPTION}

IHNFG-4866 is a nearly complete mandible. However, the right condylar and angular process are missing (Figures 3A and 3B). Both tooth rows are complete and included the p4-m3. The diastema length (DL) is shorter (nearly $90 \mathrm{~mm}$ ) than the toothrow length (TL: $100.5 \mathrm{~mm}$ in the left toothrow, $110 \mathrm{~mm}$ in the right toothrow). The internal distance between the alveoli of the p4 (IDA) in its lingual portion is $34 \mathrm{~mm}$. The masseteric crest is robust and more retracted than in Hydrochoerus hydrochaeris and begins below the Pr.I (first prism) of $\mathrm{p} 4$. The masseteric fossa in the two portions of the mandible is located below the Pr.I of the $\mathrm{ml}$ and the distance of the masseteric fossa (DMF) through the Pr.I of the $\mathrm{ml}$ is $97 \mathrm{~mm}$.

Like in all rodents, the lower incisors lack enamel in their lingual portion (Hillson, 2005). They are robust and have an anteromedial canal with longitudinal grooves in the labial portion. The alveolus of the incisors extends below the h.s.i. (secondary internal fissure) of the $\mathrm{ml}$. Both p4 show the Pr.s.a. (secondary anterior prism), Pr.I and Pr.II are joined by a small enamel bridge. The h.4i. (fourth internal fissure) is not present and the h.2e. (second external fissure) extends to more than $90 \%$ of the total width of the prism. The junction of Pr.I and Pr.II is flanked by h.1e. (first external fissure) in the labial portion and in the lingual portion by the h.s.i.p. (principal secondary internal fissure) leaving a narrow enamel bridge. The Pr.s.a. has a Y shape like the Pr.I, while Pr.II has a V shape. The length of the $\mathrm{p} 4$ is greater than the length of the $\mathrm{m} 2$, this feature is characteristic of $\mathcal{N}$. aesopi (Mones, 1991).

The $\mathrm{ml}$ presents the Pr.IIa joined to Pr.IIb in the labial portion by a thin bridge of enamel; the h.p.i. (primary internal fissure) is deep, exceeding $90 \%$ of the width of the prisms but does not separate them. The Pr.I and Pr.IIb are Y shape, while the Pr.IIa are $\mathrm{V}$ shape. Both $\mathrm{m} 2$ possess complete Pr.Ia and Pr.IIb. On the left molar the h.t.i. (tertiary internal fissure) does not divide the Pr.IIa into Pr.IIa' (anterior plate of the second prism) and Pr.IIb' (posterior plate of the second prism) and maintain the union of the enamel bridge in the labial portion (Figure 3G). This feature has been observed in juveniles and young adults of $H$. hydrochaeris, but it is a rare feature in adults (Mones, 1975a) and cannot be seen in the right $\mathrm{m} 2$ because that area is damaged. The right $\mathrm{m} 3$ has the Pr.I divided into two plates; the Pr.IIb has an abnormal widening making the h.s.e. shorter. The left $\mathrm{m} 3$ has a complete Pr.I; the h.s.i. exceeds $90 \%$ of the total width and the h.s.e. is deep, exceeding $90 \%$ of the width of the molar. The complete prisms have a $\mathrm{V}$ shape.

IHNFG-4865 is a right maxillary fragment with the M3 (Figure 4A). It is composed of 16 prisms of which Pr.I is incomplete in its mesial portion and Pr.XVI is represented only by a fragment of enamel laminae. The length of the M3 is 59.12 $\mathrm{mm}$ and the width is $20.67 \mathrm{~mm}$. The prisms in the mesial portion are robust and tend to thin out at their distal portion.

IHNFG-4873 corresponds to the anterior portion of the left hemimandible of a juvenile with incisor, $\mathrm{p} 4, \mathrm{ml}$, and an associated unidentified upper molar fragment (Figures $4 \mathrm{~B}$ and $4 \mathrm{C}$ ). The specimen preserves the distal portion of the masseteric crest and the masseteric fossa is located below the Pr.II of $\mathrm{ml}$. It retains most of the incisor, which presents the anteromedial groove and poorly marked longitudinal striations. The p4 shows the Pr.s.a. and Pr.I in Y shape while Pr.II has V shape. The Pr.s.a. is similar to the adult 

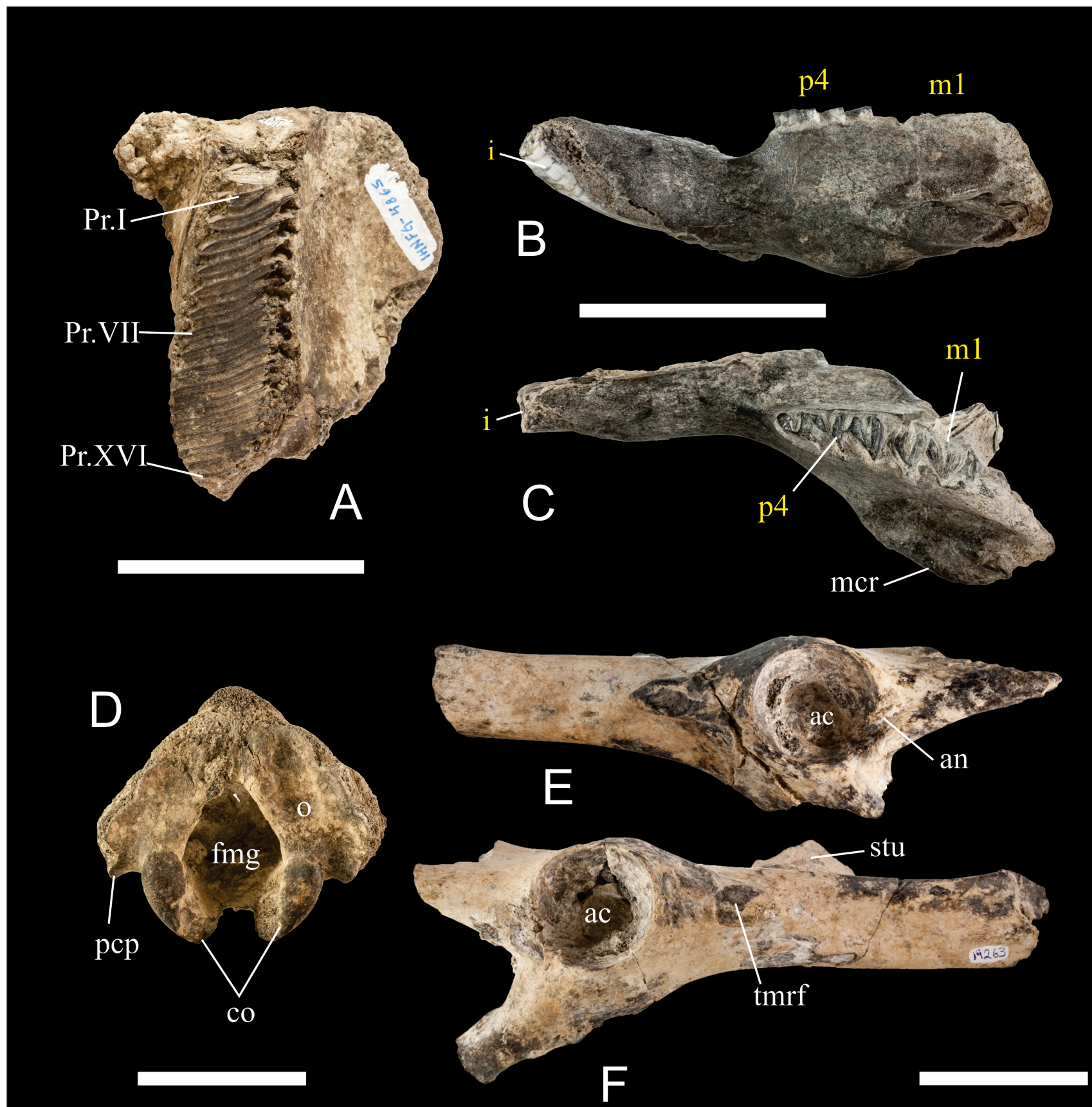

Figure 4 Dental, cranial and postcranial material of Neochoerus aesopi from Los Mangos locality, Villaflores, Chiapas. IHNFG-4865, right M3 in occlusal view (A); IHNFG-4873, left hemimandible in lateral (B) and occlusal (C) views; IHNFG-5760, parietal (D); IHNFG-5761, pelvic girdle (E and $\mathrm{F}$ ). Bar scale in all cases equal to $50 \mathrm{~mm}$. Abbreviations: ac, acetabulum; an, acetabular notch; co, condyle; fmg, foramen magnum; mcr, masseteric crest; o, occipital bone; pcp, paracondylar process; stu, sacral tuberosity; tmrf, tuberosity for the m. rectus femoris. Dental abbreviations as in Figure 2. 
specimen with the exception of the h.5i. (fifth internal fissure), which is deeper. The h.4i. is little marked and, like the adult, the union between Pr.I and Pr.II is very thin. Only the shape of the prisms can be observed in the $\mathrm{ml}$ and, unlike the adult specimen, the Pr.I and Pr.IIa have a V shape and Pr.IIb has a Y shape.

IHNFG-5760 is an occipital portion of the skull (Figure 4D) and is similar to the occipital of Hydrochoerus hydrochaeris. The occipital bone is almost flat, with a smooth depression in each side of the foramen magnum. The condyles are thin and border the lower part of the foramen magnum. The foramen magnum is oval in shape. The paracondylar processes are small and are at the level of the upper end of the occipital condyle.

IHNFG-5761 is a pelvic girdle partially conserved and resembles the pelvis of the extant capybara $H$. hydrochaeris. In ventral view, the hip bones are elongated and narrow and with an $\mathrm{Y}$ shape. The ilium is straight. The distal part of both ilium is missing but it is notorious that the ilium wing lay in a sagittal plane. The upper side of the body of the right ilium preserves the proximal part of the sacral tuberosity, which is thin in lateral-medial direction. The body of the ilium bears a prominent tuberosity for the $m$. rectus femoris. Only the iliopubic eminence of the ilium is preserved. The pubis is not preserved and is only observed as part of the branch of the pubis. The acetabulum is deep and circular in shape, with a smooth acetabular notch located in the posterior margin (Figure 4E).

\section{Discussion}

\subsection{TAXONOMIC ASSESSMENT}

The Neochoerus genus can be distinguished from the close relative Hydrochoerus by the following: Neochoerus is almost twice as large; the rostrum is longer; the anterior portion of the zygomatic arc is more rounded and oriented backward; the anterorbital bar and lacrimal are more robust; the skull roof is wider; the supraoccipital is wider and more excavated; the masseteric crest is retracted; the coronoid process is greatly reduced; and the M3 has 14 to 17 prisms, while Hydrochoerus has $12-13$ prisms (Mones, 1991; Flynn, 2008). In the mandible IHNFG-4866, the masseteric crest is retracted and the coronoid process is slightly elevated, while in the M3 IHNFG-4865 16 prisms are observed. In addition, the measurements of IHNFG-4865 and IHNFG-4866 fall within the observed range of Neochoerus (Figures 5A and 5B). All these characteristics allow us to assign the fossil material from Chiapas to the genus Neochoerus.

The North American species in the genus Neochoerus can be differentiated by its size and dental morphology. In the oldest species, $\mathcal{N}$. cordobai and $\mathcal{N}$. occidentalis, the central laminas of the M3 bear small invaginations in the labial side (Carranza-Castañeda and Miller, 1988; Carranza-Castañeda, 2016), called extraordinary external fissures (Mones, 1991). Apparently, this feature is a primitive dental character in the capybaras, because it is also present in the M3 of the Pliocene taxa Phugatherium, "Chapalmatherium" and Hydrochoeropsis (Deschamps et al., 2013; Vucetich et al., 2014). This dental morphological characteristic is not present in the M3 of $\mathcal{N}$. aesopi.

Another difference between $\mathcal{N}$. cordobai, $\mathcal{N}$. occidentalis, and $\mathcal{N}$. aesopi is observed in the DL. The $\mathrm{DL}$ in $\mathcal{N}$. cordobai and $\mathcal{N}$. occidentalis is between 60 and $70 \mathrm{~mm}$, while in $\mathcal{N}$. aesopi it is $70-90 \mathrm{~mm}$. In specimen IHNFG-4865, the M3 does not have the extraordinary external fissures on the laminas like $\mathcal{N}$. aesopi. In the same way, the mandible of IHNFG-4866 has a DL of $90.05 \mathrm{~mm}$, longer than the DL of $\mathcal{N}$. cordobai and $\mathcal{N}$. occidentalis, falling into the range of $\mathcal{N}$. aesopi.

\subsection{HYDROCHOERUS IN MEXICO?}

Material of capybaras from Chapala lake, Jalisco; Terapa, Sonora; Media Luna lagoon, San Luis Potosí; and Valsequillo, Puebla, have been referred to Hydrochoerus (Álvarez, 1971; Hernández-Junquera, 1977; Pichardo, 1997; Mead et al., 2006; Carranza-Castañeda, 2016). 

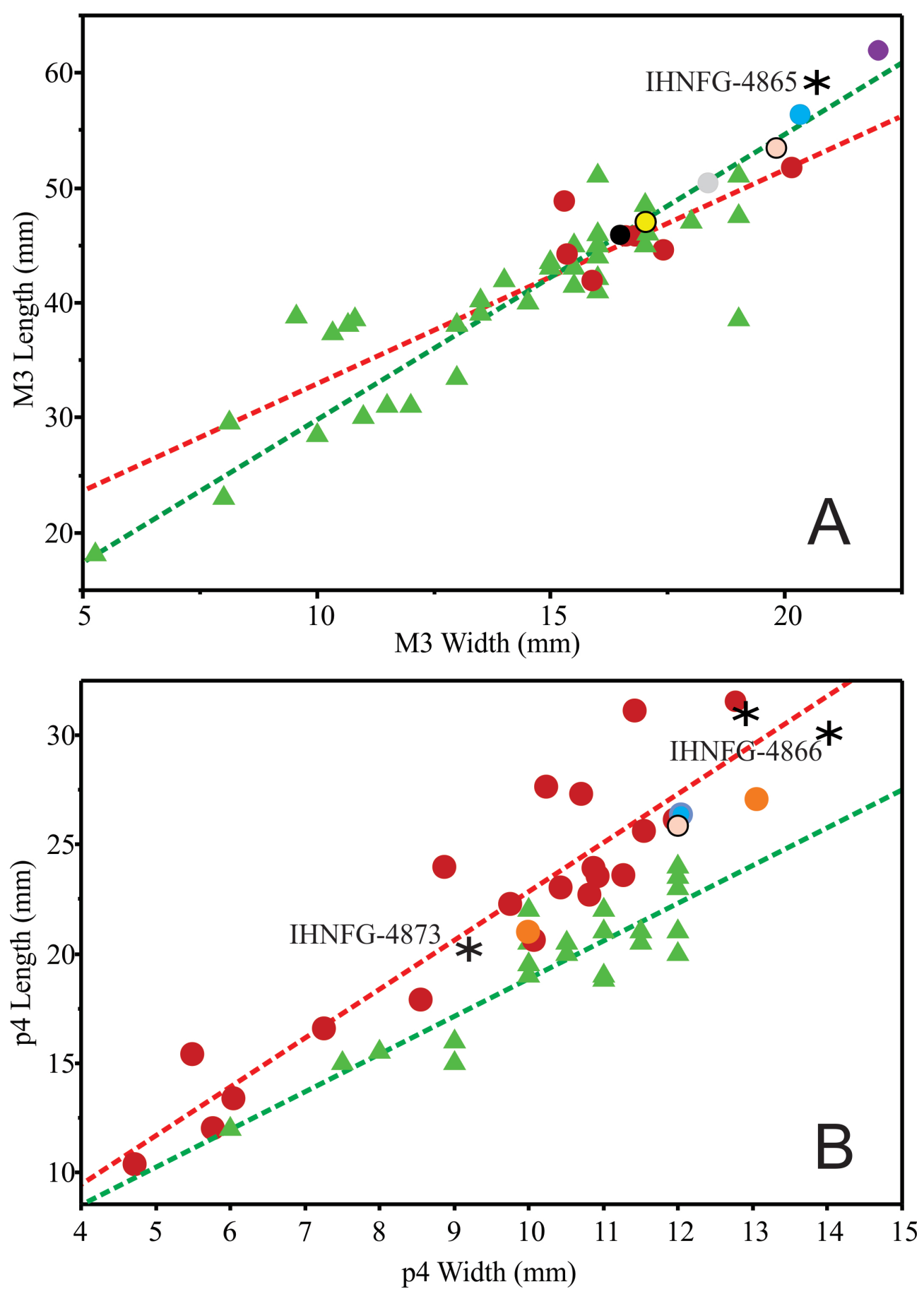

Figure 5 Bivariate plot of M3 and p4 measurements. Black asterisks: Neochoerus aesopi from Villaflores, Chiapas; red dots: N. aesopi from Chapala Lake, Jalisco (INAH, Mexico City, not catalogued); black dot: N. aesopi from Valsequillo, Puebla (INAH CDMX, “66-I; Y-I"); purple dot: $N$. pinckneyi (= N. aesopi, Sanders, 2002); blue dots: $N$. aesopi mean (Mones, 1991); pink dots: $N$. sulcidens mean (Mones, 1991); gray dot: N. tarijensis mean (Mones, 1991); yellow dot: $N$. cordobai (Carranza-Castañeda and Miller, 1988); orange dots: $N$. occidentalis (Carranza-Castañeda, 2016); green triangles: Hydrochoerus hydrochaeris (Kerber and Ribeiro, 2011). Red lines: trend of the genus Neochoerus; green lines: trend of the genus Hydrochoerus. 


\subsubsection{SPECIMENS FROM GHAPALA LAKE}

Álvarez (1971) referred the specimens from Chapala lake as Hydrochoerus. Recently, Carranza-Castañeda (2016) reviewed this material and mentioned that some specimens have characteristics of Hydrochoerus, and referred the specimens labeled with the numbers 78 and 126 as Hydrochoerus sp. (fig. 9, p. 310). Nevertheless, a review of these specimens from Chapala (housed at the Laboratorio de Arqueozoología, INAH), by one of the authors (JEP) showed that these specimens have the Neochoerus mandibular characteristics mentioned by Mones (1991) that allows the differentiation of Neochoerus from Hydrochoerus. Such differences are more evident in the DL and the TL. In H. hydrochaeris the range of the DL is $35-52.1 \mathrm{~mm}$, while in H. isthmius it is 34.6-41.7 mm (Mones, 1991). In Neochoerus the DL has a longer range (60-90 mm).

In the same way, in the Neochoerus species, the TL range is between 90 and $112 \mathrm{~mm}(\mathcal{N}$. cordobai $=112 \mathrm{~mm}, \mathcal{N}$. aesopi $=90-110 \mathrm{~mm}, \mathcal{N}$. sulcidens $=102.6 \mathrm{~mm}, \mathcal{N}$. tarijensis $=101 \mathrm{~mm})$, while in Hydrochoerus the TL range is $61.5-91.4 \mathrm{~mm}(H$. hydrochaeris $=64-91.4 \mathrm{~mm}, \mathrm{H}$. isthmius $=61.5-71.5$ $\mathrm{mm}$ ) (Mones, 1991). Specimen 78 from Chapala has a DL of $71.97 \mathrm{~mm}$ and a TL of $99.26 \mathrm{~mm}$, measurements within the range of Neochoerus. Additionally, the masseteric crest begins between the Pr.s.a and the Pr.I (like in Neochoerus), while in Hydrochoerus it begins in the anterior part of the Pr.s.a. On the other hand, specimen 126 has a DL of $40.3 \mathrm{~mm}$ and a TL of $89.87 \mathrm{~mm}$, measurements within the range of Hydrochoerus. However, the $\mathrm{p} 4$ length is greater than the $\mathrm{m} 2$ length, and the masseteric crest begins in the posterior part of the Pr.s.a, characteristics of $\mathcal{N}$. aesopi (Mones, 1991). The DL and TL measurements of the specimen are indicative of one young individual.

The M3 also exhibits differences between Neochoerus and Hydrochoerus. Although the general morphology is similar, the number of prisms varies. In Neochoerus, the number of prisms is 14 to 17, while in Hydrochoerus it is 12 to 13 (Mones, 1991;
Flynn, 2008). In some individuals from Chapala, the M3 has 14 prisms (also mentioned by Carranza-Castañeda, 2016), which allows assigning the specimens to Neochoerus. The size of the M3 in some specimens from Chapala falls into the range of Hydrochoerus, whereas the taxonomic assignation to Neochoerus or Hydrochoerus is difficult (Figure 5A).

However, the variation in the size of the teeth of capybaras is a consequence of age, which does not affect significantly the morphological characteristics (Vucetich et al., 2005). Therefore, the small size of some individuals is the result of age, and not due to specific differentiation.

The bivariate plot of the $\mathrm{p} 4$ (Figure $5 \mathrm{~B}$ ) shows that the size of this molar is more informative and a better indicator for Neochoerus to Hydrochoerus differentiation, although it is the most morphologically variable tooth (Álvarez, 1971).

Finally, the presence of Hydrochoerus in Chapala lake is rejected, because the coexistence of two or more species with the same ecological requirements within the same area is not possible.

\subsubsection{THE CAPYBARA FROM VALSEQUILLO, PUEBLA}

Hydrochoerus remains have been reported from Valsequillo, Puebla (Pichardo, 1997). However, these remains have not been illustrated. Later, Pérez-Crespo et al. $(2014,2019)$ mentioned the presence of Neochoerus sp. in Valsequillo. However, they are not specific on the basis of the taxonomic assignment.

The examination of the incomplete skull from Valsequillo (housed at Laboratorio de Arqueozoología, INAH, labeled with the number "66-I; Y-I") allow us to assign this specimen to Neochoerus aesopi. The taxonomic assignation is based on the morphological characteristics of the skull and the M3. The skull roof is wider than Hydrochoerus, with the supraoccipital wider and more excavated; lacrimal more robust and higher, and the M3 with 15 laminae, and these without extraordinary external fissures. The size of M3 indicates that this specimen is from a juvenile (Figure 5A). 


\subsubsection{HYDROCHOERUS FROM TÉRAPA AND MEDIA LUNA LAGOON}

Fossil remains of capybaras from Térapa have been referred to Hydrochoerus sp. (Mead et al., 2006) and Hydrochoeridae indeterminate (Nunez et al., 2010). However, this material has never been described or illustrated. Unfortunately, the repository of these fossils is not mentioned and therefore a revision is not possible. Further, the fossil of capybaras from Media Luna lagoon, San Luis Potosí, assigned as Hydrochoerus sp. (Hernández-Junquera, 1977), was never formally deposited in a museum and is now missing (Ferrusquía-Villafranca, 2018, pers. com.). Nevertheless, we do believe that the capybaras from Térapa and Media Luna lagoon are Neochoerus, and, considering the temporal range (late Pleistocene, Rancholabrean) assigned for both faunas, it is possible to refer this material as $\mathcal{N}$. aesopi.

Such affirmation is based upon two assumptions: (1) Mones (1984) considered that the reports of Hydrochoerus in North America are misidentifications of Neochoerus, and (2) the review of the specimens from Chapala and Valsequillo, identified as Hydrochoerus, showed that they are actually Neochoerus.

\subsection{PALEOEGOLOGICAL SIGNIFICANGE}

The paleoecological aspects of the extinct capybaras have been inferred by comparison with the extant species of Hydrochoerus. Recent capybaras are semiaquatic and live within lowlands habitats in the proximity of water, like forested riverbanks, former riverbeds, brackish wetlands, and mangrove swamps (Mones and Ojasti, 1986).

Fossil capybaras are usually recovered from fluvial, lacustrine or swampy deposits (Vucetich et al., 2013), so the lifestyle related to water is supported. Therefore, the presence of Neochoerus aesopi in Los Mangos locality indicates the existence of permanent water bodies in the area during the late Pleistocene, which is consistent with the lithology of the outcrops in the study locality. The feeding habits of Neochoerus can also be inferred through comparison with feeding habits of $H$. hydrochaeris.

Hydrochoerus hydrochaeris consumes grasses, aquatic plants, and occasionally bark, stems, and leaves (Ojasti, 1973). Recent observations show that $H$. hydrochaeris has preference for Hymenachne amplexicaulis (an aquatic grass) during the wet season, and feeds on Eleocharis interstincta (a reed) and Paratheria prostrata (a grass) during the dry season (Barreto and Quintana, 2013).

Based on the feeding habits of $H$. hydrochaeris, it is possible to infer that $\mathcal{N}$. aesopi from Los Mangos locality fed on different types of grasses, reeds, and shrubbery. This assumption is supported by the microwear and stable isotopes analyses of $\delta^{13} \mathrm{C}$ and $\delta^{18} \mathrm{O}$ on $\mathcal{N}$. aesopi from La Cinta-Portalitos, Michoacán-Guanajuato and Valsequillo, Puebla, and shows that some individuals have a mixed feeder diet based on C3/C4 plants and other individuals were C4 grazers (Pérez-Crespo et al., 2014; Eng-Ponce et al., 2017; Eng-Ponce, 2018). These data are similar to that obtained from $\mathcal{N}$. tarijensis from Bolivia, species referred to as a C3/ C4 mixed feeder (MacFaden and Shockey, 1997).

\section{Conclusions}

The formal description of the capybara fossil remains from Villaflores, Chiapas, allows us to confirm the specific taxonomy assignation as Neochoerus aesopi, which adds a new locality for this taxon in Mexico. It also documents the southernmost record, until now, for North America, and increases the spatial range of Neochoerus in the late Pleistocene.

The historical presence of Hydrochoerus in Chapala lake, Jalisco, and Valsequillo, Puebla, is rejected based upon the review of the specimens housed in Laboratorio de Arqueozoología, INAH, and confirms that the only species present in both areas is Neochoerus aesopi. In the same way, we refer 
the capybaras from Térapa and Media Luna lagoon as $\mathcal{N}$. aesopi. The presence of $\mathcal{N}$. aesopi from Sonora to Chiapas allows us to hypothesize that this was the only capybara species present in the late Pleistocene of Mexico.

\section{Acknowledgements}

The specimens described in this study were collected with the support of the project "Prospección y resguardo del patrimonio paleontológico de Chiapas", financed by the Government of Chiapas state. We thank Joaquín Arroyo-Cabrales for the permission to review the capybaras from Valsequillo and Chapala housed at Laboratorio de Arqueozoología, INAH. We are grateful to the wikipaleo community for sharing bibliography, and Torrey Nyborg for the English review of the manuscript.

Finally, we wish to thank Alvaro Mones and an anonymous reviewer for the helpful suggestions they made, and Francisco J. Vega for the editorial support.

\section{References}

Álvarez, T., 1969, Restos fósiles de mamíferos de Tlapacoya, Estado de México (PleistocenoReciente): Miscellaneous publication, University of Kansas, Museum of Natural History, 51, 93-112.

Álvarez, T., 1971, Variación de la figura oclusal del premolar inferior en carpinchos fósiles (Rodentia: Hydrochoeridae) de Jalisco, México: Instituto Nacional de Antropología e Historia, Serie Investigaciones, 21, 1-35.

Barreto, G.R., Quintana, R.D., 2013, Foraging strategies and feeding habits of capybaras, in Moreira, J.R., Ferraz, K.M.P.M.B., Herrera, E.A., Macdonald, D.W. (eds.),
Capybara, biology, use and conservation of an exceptional neotropical species: New York, USA, Springer, 83-96. https://doi. org/10.1007/978-1-4614-4000-0_4

Bell, C.J., Lundelius Jr., E.L., Barnosky, A.D., Graham, R.W., Lindsay, E.H., RuezJr., D.R., Semken Jr., H.A., Webb, S.D., Zakrzewski, R.J., 2004, The Blancan, Irvingtonian, and Rancholabrean mammal ages, in Woodburne, M.O. (ed.), Late Cretaceous and Cenozoic mammals of North America: Biostratigraphy and geochronology: New York, USA, Columbia University Press, 232-314. https://doi.org/10.7312/ wood13040-009

Bode, F.F., Fernández, J.A., Cao, J.A., Resoagli, J.M., 2013, Descripción del esqueleto axial del carpincho (Hydrochoerus hydrochaeris): Revista Veterinaria, 24(1), 44-46.

Bowdich, T.E., 1821, An analysis of the natural classifications of Mammalia for the use of students and travelers: Paris, France, J Smith, $115 \mathrm{p}$.

Brombini, G.G., Rahal, S.C., Schimming, B.C., Santos, I.F.C., Tsunemi, M.H., Mamprim, M.J., Alves, L.S., Filadelpho, A.L., Teixeira, C.R., 2018, Radiological and osteological study of the pelvic limbs in free-ranging capybaras (Hydrochoerus hydrochaeris): Anatomia, Histologia, Embryologia, 47(3), 239-249. https://doi.org/10.1111/ ahe. 12349

Carbot-Chanona, G., Gómez-Pérez, L.E., 2014, Adición al registro de megamamíferos del Pleistoceno tardío de Chiapas, México (abstract), in II Simposio de Paleontología en el Sureste de México: Puerto Escondido, Oaxaca, Mexico, Universidad del Mar, 24.

Carranza-Castañeda, O., 2016, Roedores caviomorfos (Rodentia Hydrochoeridae) del Blancano temprano-tardío - Irvingtoniano de los estados de Guanajuato, Jalisco y 
Sonora, México: relación con Phugatherium dichroplax: Revista Mexicana de Ciencias Geológicas, 33(3), 297-315.

Carranza-Castañeda, O., Miller, E.W., 1988, Roedores caviomorfos de la Mesa Central de México, Blancano temprano (Plioceno tardío) de la fauna local Rancho Viejo, Estado de Guanajuato, México: Revista Mexicana de Ciencias Geológicas, 7(2), 182-199.

Carranza-Castañeda, O., Ferrusquía-Villafranca, I., Miller, W.E., 1981, Roedores caviomorfos pliocénicos de la región central de México (abstract), in Anais Do II Congreso LatinoAmericano de Paleontología: Porto Allegre, Brazil, 721-729.

Deschamps, C.M., Vucetich, M.G., Montalvo, C.I., Zárate, M.A., 2013, Capybaras (Rodentia, Hydrochoeridae, Hydrochoerinae) and their bearing in the calibration of the late Miocene-Pliocene sequences of South America: Journal of South American Earth Sciences, 48, 145-158. https://doi. org/10.1016/j.jsames.2013.09.007

Eng-Ponce,J.,2018,Perezosos(Xenarthra:Folivora) y capibaras (Rodentia: Hydrochoerinae) del yacimiento pleistocénico (Rancholabreano) de la Cinta-Portalitos, MichoacánGuanajuato, México: Morelia, Michoacán, Universidad Michoacana de San Nicolás de Hidalgo, Bachelor thesis, 83 p.

Eng-Ponce, J., Díaz-Sibaja, R., Marin-Leyva, A.H., Arroyo-Cabrales, J., García-Zepeda, M.L., 2017, Análisis preliminar de la dieta y el hábitat de Neochoerus aesopi (Caviidae, Hydrochoerinae) de la Cinta-Portalitos, Michoacán-Guanajuato, México (abstract), in XV Congreso Nacional de Paleontología: San Luis Potosí, México, Sociedad Mexicana de Paleontología, 42.

Ferrusquia-Villafranca, I., Flynn,L.J., RuizGonzalez, J. E., Torres-Hernandez, J. R., Martinez-Hernandez, E., 2018, New Eocene rodents from northwestern
Oaxaca, southeastern Mexico, and their paleobiological significance, Journal of Vertebrate Paleontology, 38(5), e1514615. https://doi.org/10.1080/02724634.2018.1 514615

Fischer, G., 1817, Adversaria zoologica 1: Mémoires de la Société Impériale des Naturalistes de Moscou, 5, 357-446.

Flynn, L.J., 2008, Hystricognathi and Rodentia incertae sedis, in Janis, G.M., Gunnell, G.F., Uhen, M.D. (eds.), Evolution of Tertiary mammals of North America, Volume 2: Small mammals, xenarthrans, and marine mammals: Cambridge, UK, Cambridge University Press, 498-506.

Gervais, H., Ameghino, F., 1880, Les mammifères fossiles de l'Amérique du Sud/Los mamíferos fósiles de la América del Sud: Paris-Buenos Aires, F. Savy and Igon Hermanos, 225 p.

Gill, T., 1872, Arrangements of the families of mammals with analytical tables: Smithsonian Miscelaneous Collections, 11(1), 1-998.

Gómez-Pérez, L.E., Carbot-Chanona, G., 2012, Contribución al estudio de los megamamíferos del Pleistoceno Tardío del municipio de Villaflores, Chiapas, México: Lacandonia, 6(1), 31-41.

Gray, J.E., 1825, An outline of an attempt at the disposition of the Mammalia into tribes and families with a list of the genera apparently appertaining to each tribe: Annals of Philosophy (new series), 10, 337-344.

Hay, O.P., 1923, The Pleistocene of North America and its vertebrated animals from the state east of the Mississippi River and from the Canadian Provinces east of longitude 95': Carnegie Institute of Washington Publication, 322, 1-499.

Hay, O.P., 1926, A collection of Pleistocene vertebrates from southwestern Texas: Proceedings of the United States National Museum, 68(2625), 1-18. https://doi. org/10.5479/si.00963801.68-2625.1 
Hernández-Junquera, A., 1977, Fauna local Laguna de la Media Luna, Pleistoceno Tardío, Municipio de Río Verde, San Luis Potosí, México: Ciudad de México, Universidad Nacional Autónoma de México, Bachelor thesis, $102 \mathrm{p}$.

Hillson, S., 2005, Teeth: England, Cambridge University Press, 373 p.

Hoffstetter, R., 1952, Les mamifères pléistocènes de la Rèpublique de l'Équateur: Mémories de la Société Géologique de France (nouvelle série), 66, 1-391.

Kerber, L., Ribeiro, A.M., 2011, Capybaras (Rodentia: Hystricognathi: Hydrochoeridae) from the late Pleistocene of southern Brazil: NeuesJahrbuchfürGeologieundPaläontologie - Abhandlungen, 261(1), 1-18. https://doi. org/10.1127/0077-7749/2011/0142

König, H.E., Liebich, H.-G., 2007, Veterinary anatomy of domestic mammals: Stuttgart, Germany, Schattauer, 768 p.

Kraglievich, L., 1930, Los más grandes carpinchos actuales y fósiles de la subfamilia Hydrochoerinae: Anales de la Sociedad Científica Argentina, 110, 233-250.

Kurtén, B., Anderson, E., 1980, Pleistocene mammals of North America: New York, USA, Columbia University Press, 422 p.

Leidy, J., 1853, Remarks on several fossil teeth: Proceedings of the Academy of Natural Sciences of Philadelphia, 6, 241.

Leidy, J., 1856, Notice of some remains of extinct vertebrated animals: Proceedings of the Academy of Natural Sciences of Philadelphia, 8, 163-165.

Leidy, J., 1887, Toxodon and other remains from Nicaragua: Proceedings of the Academy of Natural Sciences of Philadelphia, 38(1886), 275-277.

Linnaeus, C., 1758, Systema Nature per regna tria naturae, secundum classes, ordines, genera, species cum characteribus, differentiis, synonymis, locis, Tomus I: Stockholm, Sweden, Laurentii Salvii, 824 p.

Lozano-Ramos, T., Guzmán, A.F., Polaco, O.J., 2006, La mastofauna de Los Tanques, Zacatecas (abstract), in X Congreso Nacional de Paleontología: Ciudad de México, México, Instituto de Geología, Universidad Nacional Autónoma de México, Sociedad Mexicana de Paleontología, Publicación Especial, 5, 53.

Lucas, S.G., 2008, Late Cenozoic vertebrate fossil assemblages from Jalisco, Mexico, in Lucas, S.G., Morgan, G.S., Spielmann, J.A., Prothero, D.R. (eds.), Neogene Mammals: New Mexico Museum of Natural History and Science Bulletin, 44, 51-64.

Lucas, S.G., Garcia, R., Espinoza, E., Alvarado, G.E., Hurtado de Mendoza, L., Vega, E., 2008, The fossil mammals of Nicaragua, in Lucas, S.G., Morgan, G., Spielmann, Prothero, D.R. (eds.), Neogene Mammals: New Mexico Museum of Natural History and Science Bulletin 44, 417-430.

MacFaden, B.J., Shockey, B.J., 1997, Ancient feeding ecology and niche differentiation of Pleistocene mammalian herbivores from Tarija, Bolivia: morphological and isotopic evidence: Paleobiology, 23(1), 77-100. https://doi.org/10.1017/ s0094837300016651

MacPhee, R.D.E., Singer, R., Diamond, M., 2000, Late Cenozoic Land Mammals from Grenada, Lesser Antilles IslandArc: American Museum Novitates, 3302, 1-20. https://doi.org/10.1206/0003$0082(2000) 3302<0001: 1 \mathrm{clmfg}>2.0$. co;2

Mead, J.I., Baez, A., Swift, S.L., Carpenter, M.C., Hollenshead, M., Czaplewski, N.J., Steadman, D.W., Bright, J., Arroyo-Cabrales, J., 2006, Tropical marsh and savanna 
of the late Pleistocene in northeastern Sonora, Mexico: The Southwestern Naturalist, 51(2), 226-239. https://doi. org/10.1894/0038-4909(2006)51 [226:tmas ot]2.0.co;2

Mones, A., 1975a, Estudios sobre la familia Hydrochoeridae (Rodentia), V. Revalidación de sus caracteres morfológicos dentarios con algunas consideraciones sobre la filogenia del grupo: Actas del Primer Congreso Argentino de Paleontología y Bioestratigrafía, 2, 463-476

Mones, A., 1975b, Estudios sobre la familia Hydrochoeridae (Rodentia), VI. Catálogo anotado de los ejemplares-tipo: Comunicaciones Paleontológicas del Museo de Historia Natural de Montevideo, 5(1), 99-128.

Mones, A., 1984, Estudios sobre la familia Hydrochoeridae, XIV. Revisión sistemática (Mammalia: Rodentia): Senckenbergiana Biologica, 65, 1-17.

Mones, A., 1991, Monografía de la familia Hydrochoeridae (Mammalia: Rodentia): Courier Forschungsinstitut Senckenberg, 134, 1-235.

Mones, A., Ojasti, J., 1986, Hydrochoerus hydrochaeris: Mammalian Species, 264, 1-7.

Nunez, E.E., Macfadden, B.J., Mead, J.I., Baez, A., 2010, Ancient forests and grasslands in the desert: Diet and habitat of Late Pleistocene mammals from Northcentral Sonora, Mexico: Palaeogeography, Palaeoclimatology, Palaeoecology, 297(2), 391-400. https://doi. org/10.1016/j.palaeo.2010.08.021

Ojasti, J., 1973, Estudio biológico del chigüire o capibara: Caracas, Venezuela, Fondo Nacional de Investigaciones Agropecuarias, $273 \mathrm{p}$.

Pérez-Crespo, V.A., Arroyo-Cabrales, J., Alva-Valdivia, L.M., Morales-Puente, P., Cienfuegos-Alvarado, E., Otero, F.J., Ochoa-Castillo, P., 2014, La paleodieta de cinco especies de mamíferos herbívoros rancholabreanos de Valsequillo

(Puebla, México): Revista Chilena de Antropología, 30, 76-82. https://doi. org/10.5354/0719-1472.2014.36273

Pérez-Crespo, V.A., Arroyo-Cabrales, J., MoralesPuente, P., Ochoa-Castillo, P., 2019, Paleoambiente en cuatro sitios mexicanos del Pleistoceno tardío con actividad humana inferidos a partir de la fauna: Boletín de la Sociedad Geológica Mexicana, 71(2), 343-358. https://doi.org/10.18268/ bsgm2019v71n2a7

Pichardo, M., 1997, Valsequillo biostratigraphy: new evidence for Pre-Clovis date: Anthropologischer Anzeiger, 55(3-4), 233-246.

Rasband, W.S., 2012, ImageJ: Image processing and analysis in Java: Astrophysics Source Code Library, 1, 06013.

Rufolo, S.J., 1998, Taxonomy and significance of the fossil mammals of Lake Chapala, Jalisco, Mexico: Provo, Utah, Brigham Young University, $\mathrm{PhD}$ dissertation, $292 \mathrm{p}$.

Sanders, A.E., 2002, Additions to the Pleistocene mammal faunas of South Carolina, North Carolina, and Georgia: Transactions of the American Philosophical Society, 92(5), 1-152. https://doi.org/10.2307/4144916

SAS Institute, 2008, JMP®, Version 8.0: SAS Institute Inc., Cary, NC, 1989-2019.

Shaw, G.A., 1981, The Middle Pleistocene El Golfo Local Fauna from northwestern Sonora, Mexico: California, USA, California State University, MSc Thesis, 282 p.

Shaw, G.A., McDonald, H.G., 1987, First record of giant anteater (Xenarthra, Myrmecophagidae) in North America: Science, 236(4798), 186-188. https://doi. org/10.1126/science.236.4798.186

Simpson, G.G., 1928, Pleistocene mammals from a cave in Citrus County, Florida: American Museum Novitates, 328, 1-16.

Spillmann, F., 1941, Über einen neuen Hydrochoeren Riesennager aus dem 
Pleistozän von Ekuador: Transactions and Proceedings of the Palaentological Society of Japan, 20, 27-32. https://doi.org/10.14825/ prpsj 1935.1941.27

Spillmann, F., 1948, Beiträge zur Kenntnis eines neuen gravigraden Riesensteppentieres (Eremotherium carolinense gen. et sp. nov.), seines Lebensraumes und seiner Lebensweise: Palaeobiologica, 8, 231-279.

Tullberg, T., 1899, Ueber das System der Nagethiere, eine phylogenetische Studie: Nova Acta Regiae Societatis Scientiarum Upsalensis, 18, Sectio Medica et Historiae Naturalis, 1-514. https://doi.org/10.5962/ bhl.title. 1733

Vucetich, M.G., Deschamps, C.M., Olivares, A.I., Dozo, M.T., 2005, Capybaras, size, shape, and time: A model kit: Acta Palaeontologica Polonica, 50(2), 259-272.

Vucetich, M.G., Deschamps, C.M., Pérez, M.E., 2013, Paleontology, evolution and systematics of capybara, in Moreira, J.R., Ferraz, K.M.P.M.B., Herrera, E.A., Macdonald, D.W. (eds.), Capybara, biology, use and conservation of an exceptional neotropical species: New
York, USA, Springer, 39-59. https://doi. org/10.1007/978-1-4614-4000-0_2

Vucetich, M.G., Deschamps, C.M., Pérez, M.E., Montalvo, G.I., 2014, The taxonomic status of the Pliocene capybaras (Rodentia) Phugatherium Ameghino and Chapalmatherium Ameghino: Ameghiniana, 51(3),173-183. https://doi.org/10.5710/ amgh.05.02.2014.2074

Vucetich, M.G., Deschamps, C.M., Pérez, M.E., 2015, The first capybaras (Rodentia, Caviidae, Hydrochoerinae) involved in the Great American Biotic Interchange: Ameghiniana, 52(3), 324-333. https://doi. org/10.5710/AMGH.05.02.2015.2874

Waterhouse, G.R., 1839, Observations on the Rodentia, with a view to point out the groups, as indicated by the structure of the crania, in this order of mammals: Magazine of Natural History (new series), 3, 90-96.

Woods, C.A., Kilpatrick, W., 2005, Infraorder Hystricognathi, in Wilson D.E., Reeder, D.M. (eds.), Mammal Species of the World: A Taxonomic and Geographic Reference, Third Edition: Baltimore, Maryland, The Johns Hopkins University Press, 2, 1538-1600. 